OPEN ACCESS

Vol. 8, No. 1, April, 2020

Page. $27-35$

DOI: https://doi.org/10.21107/jaffa.v8i1.7058
JOURNAL OF AUDITING, FINANCE, AND FORENSIC ACCOUNTING

E-ISSN: 2461-0607 ISSN: 2339-2886

https://journal.trunojoyo.ac.id/jaffa/index

\title{
Effects of Company Size, Profitability, Solvability and Audit Opinion on Audit Delay
}

\author{
Syaiful Bahri; Rifa Amnia
}

Institut Teknologi and Business ASIA Malang, Indonesia

\section{Article Info:}

Received: 7 March 2020

in revised form: 18 March 2020

Accepted: 30 March 2020

Available Online: 13 April 2020

\section{Keywords:}

Audit Delay, Audit Opinion, Company Size, Profitability, and Solvency

\section{Corresponding Author:}

Email: syaifulrida@gmail.com
Abstract; This study aims to analyze the effect of company size, profitability, solvency, and audit opinion on audit delay. The population of this study is LQ-45 companies listed on the Indonesia Stock Exchange in 2017-2018, but the samples employed in this study were 31 companies. The type of research data is a quantitative data of secondary sources, which analyzed with descriptive statistical analysis, classical assumption techniques, multiple linear regression analysis, coefficient of determination $R^{2}$ and $t$ test. The results of this study of solvency variables affect audit delay with a significant value of 0,000. Firm size variable has no effect on audit delay with a significant value of 0.490. The profitability variable does not affect the audit delay with a significant value of 0.098. The audit opinion variable does not affect the audit delay with a significant value of 0.313 .

Abstrak; Penelitian ini bertujuan untuk menganalisis dan menguji pengaruh ukuran perusahaan, profitabilitas, solvabilitas, dan opini audit terhadap audit delay. Populasi dalam penelitian ini adalah perusahaan LQ-45 yang terdaftar di Bursa Efek Indonesia pada 2017-2018. Sampel dalam penelitian ini adalah 31 perusahaan yang terdaftar di BEI sebanyak 31 perusahaan. Jenis data penelitian adalah data kuantitatif dan sumber data sekunder dengan analisis statistik deskriptif, teknik asumsi klasik, analisis regresi linier berganda, koefisien determinasi $\mathrm{R}^{2}$ dan uji t. Hasil penelitian variabel solvabilitas mempengaruhi audit delay dengan nilai signifikan 0,000. Variabel ukuran perusahaan tidak berpengaruh pada audit delay dengan nilai signifikan 0,490 . Variabel profitabilitas tidak mempengaruhi audit delay dengan nilai signifikan 0,098. Variabel opini audit tidak mempengaruhi penundaan audit dengan nilai signifikan 0,313. 


\section{INTRODUCTION}

Companies listed on the Indonesia Stock Exchange (IDX) are required to report financial statements that have been prepared based on the Financial Accounting Standards (SAK) and audited by auditors. One of the company obstacles in publishing financial statements to public and the Capital Market Supervisory Agency (BAPEPAM) is timeliness of auditors in completing their audit reports. The financial statements are used for the benefit of management and are also used by shareholders to assess the fund management of a company. In addition, the investors, creditors, government, public and other parties also need financial statements as the basis for decision making.

Signaling theory proposed by Ross (1977) describes that company's executives will have better information and the executives are required to provide information to investors. Investors' confidence depends on the quality of information conveyed by the company through the published financial statements. In order to gain the investor confidence, companies are required to provide a clear, accurate, and timely information that can be compared with the same indicators. Delay in submitting financial statements might decrease the investor confidence. Companies that submit financial statements provide information to the market. The delay in the financial statement submission causes unstable stock movement; so that, the investors consider it as an audit delay.

One of the causes why companies experienced delays in submitting financial statements is due to the auditor delay in completing his audit work. Audit delay exceeding time limit of the Capital Market Supervisory Agency provisions, naturally causes delays in the financial statement publication. This condition might indicate problems in a company issuer of the financial statements, which requires more time to complete the audit. Audit delay in the financial statement can give a negative impact on the company and management. The longer the delay of financial statement submission, the relevance of these financial statements is increasingly doubtful.

Every company that issues financial statements for a certain period is always expected by various parties. Hence, publishing of financial statements by the go public company must not exceed the provisions of the Capital Market Supervisory Agency, which are 90 days or at the end of the third month after the close of the accounting period. This is in accordance with the Decree of Capital Market Supervisory Agency No. $36 / \mathrm{PM} / 2003$ on periodic report obligation stating that the annual financial statements accompanied by accountants' reports with the regular opinion must be submitted to the Capital Market Supervisory Agency no later than the end of the third month (90 days) after the date of the financial statements. Public companies in Indonesia are required to be punctual in submitting financial statements as stipulated in the Decree of the Head of Capital Market Supervisory Agency Number: Kep-36/PM/2003 on the obligation to submit periodic reports (Bapepam-LK, 2003). The regulation is in accordance with the compliance theory.

There are several factors affecting audit delay such as company size, profit and loss of operation, profitability, solvability, audit opinion, and Public Accounting Firm (KAP). Company size is viewed from the asset size owned by companies. Results of research conducted by Apriliane (2015); Hakiki (2018); Nuryanti (2018); Subekti \& Widiyanti (2004) show that company size has significant effect on audit delay because the larger the company, the better the internal control is. This is likely to minimize errors when preparing financial statements, so that the auditors can carry out the audit process more quickly. Yulianti (2011) findings state that large scale companies tend to face higher external pressure to immediately announce audit reports. This indicates that the greater the company size, the shorter the audit delay is, and vice versa. Those findings are different from the findings of Sari (2017); Wijaya (2019) that the company size variable does not significantly affect the audit delay variable.

High profitability indicates that the company is experiencing profits. Companies with high profitability have a shorter audit delay because it is good news that must be immediately conveyed to investors and other interested parties. Otherwise, companies with low profitability or obtain losses might postpone their financial statement publication. Results of research conducted by Hakiki (2018); Nuryanti (2018); Subekti \& Widiyanti (2004) show that profitability affects audit delay because profitability shows 
the company's success in gaining profits.

Solvability refers to the company ability to meet its financial obligations if the company is liquidated, either short-term or long-term liabilities. Hakiki (2018); Nuryanti (2018) research results show that solvability affects audit delay because the level of the debt size will cause longer examination and reporting on the company's debt inspection. Hence, it can slow down the audit reporting process by the auditor. In contrast to the research results of Pinatih \& Sukartha (2017); Sari (2017); Wijaya (2019), solvability does not affect audit delay. As in accordance with the quality standards of the auditor, which is contained in the professional standards of public accountants carrying out company audit procedures, that either have large total debt with a large number of debt holders or companies with small debts and a small number of debt holders will not affect the financial statement audit completion process. This is because the appointed auditor must have provided time to complete the auditing process for debt.

Audit opinion is an opinion on the fairness of financial statements in the audit. Audit delay is getting longer if the companies get qualified opinion. While companies that get unqualified opinion have faster audit (Ratnawaty \& Sugiharto, 2005). The research results by Rohmana (2017); Sari (2017); Wijaya (2019) show that audit opinion affects audit delay. Those are in contrast with the research of Hakiki (2018) that audit opinion has no effect on audit delay. This is due to the auditor's opinion, which is an assessment of the company's managerial performance in a year, is not a key factor in determining the audit delay. Management has authority to determine the submission of audited financial statements to the Capital Market Supervisory Agency. The auditors do not have that authority, so the audit opinion has no effect on audit delay. The research problem is how the effects of company size, profitability, solvability, and audit opinion on audit delay.

\section{LITERATURE REVIEW AND HYPOTHESIS DEVELOPMENT}

\section{Signaling Theory}

Signaling theory is a theory proposed by (Ross, 1977). This theory states that the executives of company have a better information than stockholders and tend to provide information that can be a signal to investors and other potential parties in making economic decision. The information in the form of "good news" owned by the company related to future prospects is expected to increase the company's stock price. The benefit of signaling theory is the accuracy and timeliness of presenting financial statements to the public that becomes a signal from companies to investors for decision making. A longer audit delay causes uncertainty in stock price movements (Wiwik, 2006). Investors can interpret the length of audit delay because the company has bad news. It is considered as negative signal because the company does not immediately publish its financial statements which will affect the company stock price.

\section{Audit Delay}

Ashton et al (1987) state that audit delay is the length of time to complete an audit that is measured from the closing date of the accounting period to the date the audit report is issued. Audit delay in some research is called as audit report lag which is defined as the time difference between the end of the fiscal year and the date the audit report is issued. Dyer \& McHugh (1975) divide the lag into: preliminary lag, the interval between the end of fiscal year to the receipt date of the preliminary financial statements by the capital market, auditor's signature lag, the interval between the end of the fiscal year to the date stated in the auditor report, and total lag, the interval between the end of the fiscal year up to the receipt date of the annual report publication by the capital market.

\section{Company Size}

A company can be classified into a big or a small company from several viewpoints such as total asset value, total sales, number of workers and so on. The research results by Setyorini (2008) show that the company size which is assessed by asset values owned by the company, negatively affects the audit delay. It shows that management of a large company management tend to reduce the audit delay of financial statements. This is due to many factors, among of them are the large-scale company management that tends to be given incentives to reduce audit delay because the 
company is closely monitored by investors, capital supervisory agencies, and government.

\section{Profitability}

Profitability is a ratio to assess a company ability to earn profits (Kasmir, 2015). Low profitability is considered to affect audit delay. This is related to the impact that can be caused by the market on the announcement of loss. Carslaw \& Kaplan (1991) research explains that companies reporting losses might require auditors to arrange longer audit time than usual. The findings of Kartika (2009) research also shows that the lower profitability cause delay in the publication of financial statements.

The indicator to determine the profitability level of a company in this research was return on assets (ROA). ROA is a ratio that measures the effectiveness of the total use of natural resources. The profitability level of a company affects the time to complete the audit and the announcement of the annual financial statements. Profitability is the company ability to generate profits within a certain period. The higher the profitability, the higher the company efficiency in utilizing company facilities. The profitability of a company is measured by ROA, the profitability is estimated to affect audit delay.

\section{Solvability}

According to Periansya (2015), solvability ratio or leverage ratio is a ratio used to measure amount of assets that are financed with debts. A company that is not solvable is a company whose total debt is greater than its total assets. Companies that have high debt to asset ratio will be late in submitting financial statements because the time available is used to cover the poor conditions and they do everything possible so that these conditions are not known by interested parties on the financial statements.

\section{Audit Opinion}

According to Ardiyos (2007), audit opinion is a report provided by a registered public accountant based on an assessment of the fairness of the financial statements presented by company. According to Mulyadi (2014), there are five types of opinion of audit reports issued by auditor: unqualified opinion, modified unqualified opinion, qualified opinion, adverse opinion, and disclaimer opinion.

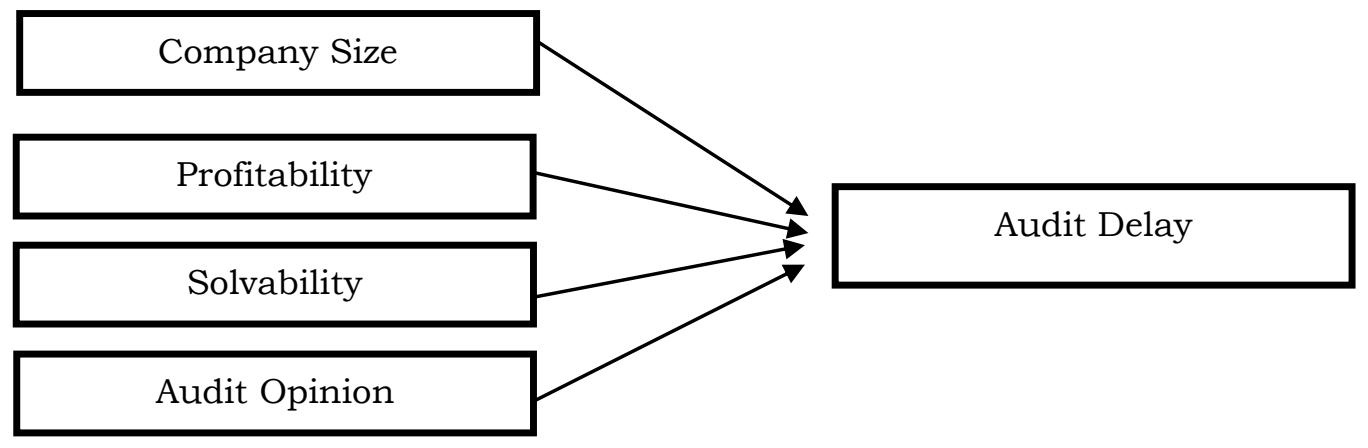

Figure 1. Conceptual Framework

\section{Hypothesis}

\section{Effects of Company Size on Audit Delay}

Research results of Apriliane (2015); Hakiki (2018); Nuryanti (2018) state that audit delay is affected by the company size, which means the audit delay will be longer if the audited company is large. This relates to the increasing number of samples that must be taken and the audit process of larger company take more time than smaller companies. Management of a large-scale company tends to be given an incentive to reduce audit delay as large companies are supervised very closely by investor, government, and capital supervisory agencies. Therefore, there are higher external pressure to announce the audited financial statements earlier (Subekti \& Widiyanti, 2004). The larger the company size, the shorter the audit delay is. Based on this thought, then the first hypothesis is formulated as follows: 
$\mathrm{H}_{1}$ : Company size affects audit delay.

Effects of Profitability on Audit Delay

Profitability is a company's ability to make profits in relation to sales, total asset, and equity. Companies with high profitability level tends to speed up the publication of their financial statements because it can increase the company value. The research results by Nuryanti (2018); Prameswari \& Yustrianthe (2015) show that profitability affects audit delay. Companies that suffer losses tend to require an auditor to start the slower auditing process than usual (Subekti \& Widiyanti, 2004). This shows that the higher the company profitability, the shorter the audit delay is, and vice versa. Companies with low profitability tend to experience longer audit report issuance (Ashton et al., 1987). Based on this thought, then the second hypothesis is formulated as follows:

$\mathrm{H}_{2}$ : Profitability level affects audit delay.

\section{Effects of Solvability on Audit Delay}

Solvability is the company ability to fulfill all financial obligations when the company is liquidated. The results of Hakiki (2018) research show that company solvability has a significant effect on audit delay. A high solvability ratio results in the length of time required for completing the audit. High amount of debt will lead to a relatively longer audit process. In such auditing process condition, auditors need to be more careful and thorough because this concerns the company survival. This shows that the higher the company solvability, the longer the audit delay and vice versa. Based on this thought, the third hypothesis is formulated as follows:

$\mathrm{H}_{3}$ : Solvability level affects audit delaiy.

\section{Effects of Audit Opinion on Audit Delay}

Carslaw and Kaplan in Saputri (2012) find the effects of audit opinion on audit delay. In companies that accept qualified opinion, they will show relatively long audit delay since the process of providing audit opinions involves negotiation with clients, consultation with more senior audit partners or other technical staff and expansion of the audit scope. The results of those research are in line with the research by Wijaya (2019) who finds that audit opinion affects audit delay. Based on this thought, the fourth hypothesis is formulated as follows:

$\mathrm{H}_{4}$ : Audit opinion affects audit delay.

\section{RESEARCH METHODOLOGY}

\section{Population}

According to Bahri (2018), population is the whole research object and meets certain characteristics. The research population was LQ-45 Companies listed on the Indonesia Stock Exchange in 2017-2018.

\section{Sample}

Samples are part of the population taken through certain ways that also have specific characteristics (Bahri, 2018). Research sample collection was based on purposive sampling criteria. This method aims to provide maximum information (Now and Nougie in Bahri, 2018). Research sample criteria were as follows:

a. LQ-45 companies listed on the Indonesia Stock Exchange of 2017-2018 period.

b. Consistently registered companies in LQ-45 during 2017-2018 period.

c. Companies that made profit during the research period.

d. Companies that used rupiah currency.

\section{Operational Definition of Variables}

1. Audit delay is the period between the closing date of the accounting period to the date the independent auditor report is signed. This variable is measured quantitatively in number of days.

2. Company size is measured using total asset. Measurement of company size variable used natural logarithms of total company assets and measurement scales used ratio scale (Jogiyanto, 2000). 
3. Profitability is proxied with return on assets (ROA) which is calculated based on net income divided by total asset (Brigham \& Houston, 2012).

4. Solvability is proxied by comparing the total asset and total debt (both short term and long term). This comparison number is stated as total debt to total asset ratio.

Audit opinion is a report provided by a registered public accountant as a result of an assessment of the fairness of financial statements presented by the company (Ardiyos, 2007). This variable is measured by dummy where opinion other than unqualified opinion is coded 1 and for unqualified opinion is coded 0 .

\section{FINDINGS AND DISCUSSION}

\section{Data Analysis Description Normality Test}

Data normality test is a distribution test of data, whether the spread is below the normal curve or not (Bahri, 2018). Testing of data normality used Kolmogrov Smirnov one-sample test. Based on research results, the kolmogrorov-smirnov/statistical test value was 0.077 with a significance level of 0.200 . If the significance value was $0.200>$ 0.05 , it was concluded that the data was normally distributed.

\section{Multiple Regression Analysis}

(Bahri, 2018) said that multiple regression analysis is an analysis that links between two or more independent variables with dependent variables. The results of multiple linear regression test are as follows:

Table 1. Linear Regression Test

\begin{tabular}{|c|c|c|c|c|c|c|}
\hline \multirow{2}{*}{\multicolumn{2}{|c|}{ Model }} & \multicolumn{2}{|c|}{$\begin{array}{c}\text { Unstandardized } \\
\text { Coefficients }\end{array}$} & \multirow{2}{*}{$\begin{array}{c}\text { Standardized } \\
\text { Coefficients } \\
\text { Beta } \\
\end{array}$} & \multirow[t]{2}{*}{$\mathrm{t}$} & \multirow[t]{2}{*}{ Sig. } \\
\hline & & B & Std. Error & & & \\
\hline 1 & (Constant) & 121,876 & 25.236 & & 4.829 & .000 \\
\hline & Profitability & -.433 & .258 & -.214 & -1.681 & .098 \\
\hline & Solvability & -56.983 & 11.089 & -.628 & -5.139 & .000 \\
\hline & Company size & -.319 & .459 & -.083 & -.695 & .490 \\
\hline & Audit Opinion & -19.205 & 18.856 & -.115 & $-1,019$ & .313 \\
\hline
\end{tabular}

a. Dependent Variable: Audit_delay

Source: Edited, 2019

Based on the table above, then the multiple linear regression equation is as follows: audit delay $=121.876-0.433$ profitability -56.983 solvability -0.319 company size 19.205 audit opinion + error.

\section{Discussion \\ Effects of Company Size on Audit Delay}

The first hypothesis is that company size affect audit delay shows a significance value of $0.490>0.05$. The result shows that company size has no significant effects on audit delay and the first hypothesis is rejected. The company size value in this research do not affect audit delay because the samples used are companies listed on the IDX supervised by investors, capital supervisory agencies, and government. These research results support the findings of Sari (2017); Wijaya (2019) that company size have no effect on audit delay. However, this study does not support the findings of Apriliane (2015); Hakiki (2018); Nuryanti (2018); Subekti \& Widiyanti (2004) that company size has a negative and significant effect on audit delay, meaning that audit delay would be longer if the company size to be audited is larger.

\section{Effects of Profitability on Audit Delay}

The second hypothesis of the effect of profitability on audit delay shows significance value of $0.098>0.05$. This result indicates that profitability has no significant effects on audit delay, so the second hypothesis is rejected. The greater the profit of the company, 
the faster the audit process is carried out, but changes in the profit level has no significant effects on audit delay. Companies that experience losses tend to require an auditor to start the slower auditing process than usual. The research result supports the findings of Hakiki (2018) that profitability has no effect on audit delay. Audit delay is not significantly affected by the company profit level because the audit process for a company that have a small profit level does not differ from the audit process for a company with large profit level. Companies that experienced either small or large profits tend to speed up their audit process. Still, the research result is different from the findings of Nuryanti (2018); Subekti \& Widiyanti (2004) that profitability affect audit delay.

\section{Effects of Solvability on Audit Delay}

The third hypothesis of the effect of solvability on audit delay shows significance value of $0.00<0.05$. The result shows that solvability has a significant effect on audit delay, so the third hypothesis is accepted. The research result supports the findings of Hakiki (2018); Nuryanti (2018) that solvability affects audit delay. A high solvability ratio results in the length of time required for completing the audit. The higher amount of debt the company has will lead to a relatively longer audit process. This is because in the auditing process, auditors need to be more careful and thorough because it is related to the company survival. It shows that the higher the company solvability, the longer the audit delay and vice versa. However, this research result is different from Sari (2017) research that solvability do not affect audit delay.

\section{Effects of Audit Opinion on Audit Delay}

The fourth hypothesis is the effect of audit opinion on audit delay that shows a significance value of $0.313>0.05$. It means the audit opinion has no significant effect towards audit delay and the fourth hypothesis is rejected. This research result supports the findings of Hakiki (2018) that audit opinion does not affect audit delay. The auditors are able to complete the audit process in a timely manner regardless the type of audit opinion issued. The auditor's opinion on financial statements apparently does not have a significant effect on the audit delay and it is not a determinant factor in audit delay. However, the research result is not consistent with the findings of Apriliane (2015); Sari (2017); Wijaya (2019) that audit opinion has a significant effect on audit delay, meaning that the audit delay is relatively long for companies that receive qualified opinions. It is because the process of providing audit opinions involves negotiation with clients, consultation with more senior audit partners or other technical staff and expansion of the audit scope. In companies that receive unqualified opinion, audit delay tends to be shorter, unqualified opinion is considered as a good news; so, the company will not delay the publication of its financial statements.

\section{CONCLUSION AND SUGGESTIONS}

\section{Conclusions}

Company size has no effect on audit delay because the company size does not determine the length of audit process. Profitability has no effect on audit delay because the audit process of companies with high profitability level is no different from companies with low profitability level. Solvability affects audit delay. A high solvability ratio results in the length of time required for completing the audit. High amount of debt the companies have will lead to a relatively longer audit process. Audit opinion has no effect on audit delay. The auditors carry out the audit process according to the planned time and not affected by the audit opinion issued.

\section{Suggestions}

Based on the conclusions outlined, the suggestions are as follows:

1. Further researchers are suggested to add the number of variables that can affect audit delay like the auditor reputation, as an auditor with good reputation will reduce audit delay.

2. Further research is expected to add the period of observation; so that the ability to predict is getting better, and the findings will be able to portray the real condition.

Future research is expected to involve more companies other than those incorporated in LQ-45 index, so that the results can be more generalized. 


\section{REFERENCES}

Apriliane, M. D. (2015). Analisis Faktor-Faktor yang Mempengaruhi Audit Delay (Studi Empiris pada Perusahaan Pertambangan yang Terdaftar Di Bursa Efek Indonesia Tahun 2008-2013). Universitas Negeri Yogyakarta.

Ardiyos. (2007). Kamus Standar Akuntansi. Jakarta: Citra Harta Prima.

Ashton, R. H., Willingham, J. J., \& Elliott, R. K. (1987). An Emprical Analysis of Audit Delay. Journal of Accounting Research, 25(2), 275-292.

Bahri, S. (2018). Metode Penelitian Bisnis Lengkap dengan Pengolahan Data SPSS. Yogyakarta: Penerbit Andi.

Bapepam-LK. Concerning Obligation to Submit Periodic Financial Statement (2003). Indonesia: Bapepam-LK.

Brigham, E. F., \& Houston, J. F. (2012). Dasar-Dasar Manajemen Keuangan (Edisi 11). Jakarta: Salemba Empat.

Carslaw, C. A. P. N., \& Kaplan, S. E. (1991). An Examination of Audit Delay: Further Evidence from New Zealand. Accounting and Business Research, 22(85), 21-32.

Dyer, J. C. I. V., \& McHugh, A. J. (1975). The Timeliness of The Australian Annual Report. Journal of Accounting Research, 13(2), 204-219.

Hakiki, R. F. (2018). Analisis Faktor-Faktor yang Mempengaruhi Audit Delay Pada Perusahaan Jasa Keuangan di Bursa Efek Indonesia (Studi Empiris Pada Perusahaan Jasa Keuangan yang Listing Di BEI 2012-2016). Universitas Islam Indonesia Yogyakarta.

Jogiyanto. (2000). Teori Portofolio dan Analisis Investasi (Edisi II). Yogyakarta: BPFEUGM.

Kartika, A. (2009). Faktor-Faktor yang Mempengaruhi Audit Delay (Studi Empiris Pada Perusahaan LQ-45 yang Terdaftar di Bursa Efek Jakarta). Jurnal Bisnis Dan Ekonomi (JBE), 16(1), 1-17.

Kasmir. (2015). Analisis Laporan Keuangan. Jakarta: Rajawali Pers.

Mulyadi. (2014). Auditing. Jakarta: Salemba Empat.

Nuryanti. (2018). Faktor-Faktor yang Berpengaruh terhadap Audit Delay (Studi Kasus Pada Perusahaan Lq-45 yang Terdaftar Di Bursa Efek Indonesia Tahun 2013-2016. Universitas Negeri Yogyakarta.

Periansya. (2015). Analisis Laporan Keuangan. Palembang: Politeknik Negeri Sriwijaya.

Pinatih, N. W. A. C., \& Sukartha, I. M. (2017). Faktor-Faktor Yang Mempengaruhi Audit Delay Perusahaan di Bursa Efek Indonesia. E-Jurnal Akuntansi, 19(3), 2439-2467.

Prameswari, A. S., \& Yustrianthe, R. H. (2015). Analisis Faktor-Faktor yang Memengaruhi Audit Delay (Studi Empiris pada Perusahaan Manufaktur Yang Terdaftar Di Bursa Efek Indonesia). Jurnal Akuntansi, 19(1), 50-67.

Ratnawaty, \& Sugiharto, T. (2005). Audit Delay pada Industri Real Estate dan Properti yang Terdaftar di Bursa Efek Jakarta dan Faktor yang Mempengaruhi. In Seminar Nasional PESAT. Jakarta.

Rohmana, N. S. D. (2017). Faktor-Faktor Yang Mempengaruhi Audit Delay Pada Perusahaan Manufaktur Sektor Industri Barang Konsumsi Yang Terdaftar Di Bursa Efek Indonesia Tahun 2013-2015. Simki-Economic, 1(5).

Ross, S. A. (1977). The Determination of Financial Structure: The Incentive Signaling Approach. The Bell Journal of Economics, 8(1), 23-40.

Saputri, O. D. (2012). Analisis Faktor-Faktor yang Mempengaruhi Audit Delay (Studi Empiris pada Perusahaan-Perusahaan yang Terdaftar Di Bursa Efek Indonesia). Universitas Diponegoro Semarang.

Sari, W. D. (2017). Pengaruh Ukuran Perusahaan, Opini Auditor dan Debt To Total Asset Ratio Terhadap Audit Delay Universitas PGRI Yogyakarta. Universitas Islam Indonesia Yogyakart. 
Setyorini, I. (2008). Analisis Faktor-Faktor yang Mempengaruhi Lamanya Penyelesaian Audit (Audit Delay) pada Perusahaan Publik di Indonesia. Universitas Brawijaya.

Subekti, I., \& Widiyanti, N. W. (2004). Faktor-Faktor yang Berpengaruh terhadap Audit Delay di Indonesia. In Simposium Nasional Akuntansi. Denpasar Bali: Ikatan Akuntan Indonesia.

Wijaya, T. (2019). Faktor-Faktor yang Mempengaruhi Audit Delay (Studi Empiris pada Perusahaan Tambang Batu Bara Yang Terdaftar di Bursa Efek Indonesia). Institut Teknologi Asia Malang.

Wiwik, U. (2006). Analisis Determinan Audit Delay Kajian Empiris di Bursa Efek Jakarta. Buletin Penelitian, 9(1), 19-31.

Yulianti, A. (2011). Faktor-Faktor yang Berpengaruh terhadap Audit Delay (Studi Empiris pada Perusahaan Manufaktur yang Terdaftar di Bursa Efek Indonesia pada Tahun 2007-2008). Universitas Negeri Yogyakarta. 